\title{
Complex Regulation of Calcium Current in Cardiac Cells \\ Dependence on a Pertussis Toxin-sensitive Substrate, Adenosine Triphosphate, and an $\alpha_{1}$-Adrenoceptor
}

Edmund C. Keung and Joel S. Karliner

Cardiology Section, Department of Medicine, Veterans Administration Medical Center, San Francisco, California 94121; and

Cardiovascular Research Institute, University of California, San Francisco, California 94143

\begin{abstract}
We investigated regulation of the cardiac L-type calcium channel by intracellular ATP and by $\alpha_{1}$-adrenergic agonism using single adult guinea pig ventricular cells and the wholecell patch clamp method. Inclusion of $5 \mathrm{mM}$ ATP in the patch clamp pipette prevented calcium current rundown but did not increase the maximal magnitude of the slow inward calcium current $\left(I_{C_{a}}\right)$. During $\beta_{1}$-adrenergic blockade with $10 \mu M(-)$ propranolol, cells preincubated with $1 \mu \mathrm{g} / \mathrm{ml}$ pertussis toxin for 2-5 $\mathrm{h}$ exhibited a rapid twofold increase in $I_{\mathrm{Ca}_{\mathrm{a}}}$ after rupture of the membrane patch when $5 \mathrm{mM}$ ATP was present in the patch clamp pipette. In the absence of $A T P$, the increase in $I_{C_{a}}$ did not occur. In pertussis toxin-treated cells, $100 \mu \mathrm{M}(-)-$ phenylephrine inhibited the augmentation of $I_{C \cdot}$. This inhibitory effect was blocked by $100 \mathrm{nM}$ terazosin, a selective $\alpha_{1}$-antagonist. The inhibitory effect of $\alpha_{1}$-adrenergic agonism was not mediated by CAMP-dependent phosphodiesterase since incubation with $100 \mu \mathrm{M}(-)$-phenylephrine did not augment the activity of this enzyme. We conclude that regulation of the L-type calcium channel in cardiac cells is complex, and is dependent on a pertussis toxin-sensitive substrate, ATP, and an $\alpha_{1}$-adrenergic receptor. The marked increase in $I_{C}$ after pertussis toxin treatment in the presence of ATP indicates significant inhibition of $I_{C}$ by a pertussis toxin substrate, presumably the guanine nucleotide inhibitory protein $\left(G_{i}\right)$ in the basal state. The inhibitory action of (-)-phenylephrine in pertussis toxin-treated cells is consistent with modulation of $I_{\mathrm{Ca}}$ by an $\alpha_{1}$-adrenergic receptor not coupled to $G_{i}$. (J. Clin. Invest. 1990. 85:950-954.) adenosine triphosphate $\cdot \alpha_{1}$-adrenoceptor $\bullet$ calcium current $•$ pertussis toxin
\end{abstract}

\section{Introduction}

In cardiac cells the slow inward calcium current $\left(I_{\mathrm{Ca}}\right)^{1}$ or $\mathrm{L}$ type current is involved in action potential generation, activation of the pacemaker current in nodal tissue, and the initia-

Address reprint requests to Dr. Keung, Cardiology (IIIC), Veterans Administration Medical Center, 4150 Clement Street, San Francisco, CA 94121.

Received for publication 23 June 1989 and in revised form 19 October 1989.

1. Abbreviations used in this paper: $\mathrm{G}_{\mathrm{i}}$ and $\mathrm{G}_{\mathrm{s}}$, guanine nucleotide inhibitory or stimulating protein; $I_{\mathrm{Ca}}$, slow inward calcium current.

The Journal of Clinical Investigation, Inc.

Volume 85, March 1990, 950-954 tion of contraction (1). There is abundant evidence that this current is modulated by norepinephrine and acetylcholine released at nerve endings $(2,3)$. In dorsal root tissue, norepinephrine inhibits the calcium-dependent action potential by means of a reduction of $I_{\mathrm{Ca}}$ by the neurotransmitter. There is indirect evidence that this antagonist effect occurs via an $\alpha$ adrenergic receptor coupled to a $\mathbf{G}$ protein, probably the guanine nucleotide inhibitory protein $\left(G_{i}\right)$, resulting in activation of protein kinase $\mathrm{C}$ through the phosphatidylinositol pathway (4-6). Although the antagonist effect of $\alpha$-adrenergic stimulation is well established in neuronal cells, the influence of $\alpha_{1-}$ adrenergic agonism on the cardiac $I_{\mathrm{Ca}}$ is controversial; both an increase (7) or no effect have been reported (8-10). Recent observations in our laboratory indicate that in neonatal rat ventricular myocytes, the $\alpha_{1}$-adrenergic receptor acting via a pertussis toxin-sensitive substrate, presumably $G_{i}$, is linked to inhibition of cAMP metabolism (11). Based on these preliminary data, we sought to determine whether $\alpha_{1}$-adrenergic agonism had a similar effect on the cardiac $I_{\mathrm{Ca}}$ and if so, whether a pertussis toxin-sensitive $G$ protein is a component of this signal transduction mechanism. We here report that $(a)$ pretreatment of adult guinea pig heart cells with pertussis toxin results in marked augmentation of $I_{\mathrm{Ca}} ;(b)$ this increase occurs only in the presence of exogenous ATP; and $(c)$ stimulation of the $\alpha_{1}$-adrenoceptor prevents the increase in $I_{\mathrm{Ca}}$ produced by pertussis toxin.

\section{Methods}

Isolation of single ventricular cells. Single ventricular cells were freshly isolated from male guinea pigs weighing $250-350 \mathrm{~g}$ by a modification of the procedure used by Silver et al. (12). Isolated cells were incubated in minimal essential medium at $37^{\circ} \mathrm{C}$ until voltage clamp experiments were begun; the experiments were then carried out at an ambient temperature of $22-25^{\circ} \mathrm{C}$.

Voltage clamp experiments. Voltage clamp experiments were performed in the whole-cell configuration with the single-pipette patch clamp method (13) using an Axopatch-1B patch clamp system (Axon Instruments, Inc., Burlingame, CA). Pipettes were fabricated from 1.8-mm o.d. glass tubing (Microstar, Radnoti Glass, Monrovia, CA) using a microprocessor-based patch pipette puller (PC-84, Sutter Instruments, San Rafael, CA). The pipettes had an internal tip diameter of 2-2.5 $\mu \mathrm{m}$ after slight fire-polishing and a resistance of 1.5-2.0 M $\Omega$ after back-filling with the experimental internal solution. 1-4-G $\Omega$ seals between the pipette tip and the cell membrane were achieved in an external solution containing (in millimolar): $\mathrm{NaCl} 137, \mathrm{KCl} 5.4$, $\mathrm{MgCl}_{2} 1.0, \mathrm{CaCl}_{2} 1.8$, Hepes 10 , and glucose 10 at $\mathrm{pH}=7.4$ (titrated with $\mathrm{HCl}$ ). The internal pipette solution contained (in millimolar): $\mathrm{KCl} 140, \mathrm{MgCl}_{2}$ 2, Hepes $10, \mathrm{CaCl}_{2}$ 1, EGTA 11 , and $\mathrm{K}_{2} \mathrm{ATP} 5$ at pH $=7.2$ (titrated with $\mathrm{KOH})$. For the ATP-free internal solution, $\mathrm{KCl}$ was 
increased to $150 \mathrm{mM}$. The fast inward sodium current was inactivated by holding the membrane potential at $\mathbf{- 4 0} \mathrm{mV}$. Maximum peak calcium current was measured from zero current level. Voltage clamp steps were applied at $0.5 \mathrm{~Hz}$. After series resistance compensation the residual series resistance was reduced to $\sim 1 \mathrm{M} \Omega$ (average reduction of $74 \%$ ). With a mean maximal calcium current of $3,000 \mathrm{pA}$, the maximal voltage drop across the residual uncompensated series resistance error was small $(\sim 3 \mathrm{mV})$.

Pertussis toxin-catalyzed ADP-ribosylation. ADP-ribosylation was performed by a modification of the method described by Morris and Bilezikian (14). Dithiothreitol-activated pertussis toxin $(2.5 \mu \mathrm{g})$ was incubated with membrane protein ( $200 \mu \mathrm{g}$ per sample) for $2 \mathrm{~h}$ at $37^{\circ} \mathrm{C}$ in a $100-\mu$ l reaction mixture containing $\mathrm{MgCl}_{2}, 2.5 \mathrm{mM}$; thymidine, 20 $\mathrm{mM}$; ATP, $1.0 \mathrm{mM}$; EDTA, $1 \mathrm{mM}$; $\mathrm{K}_{3} \mathrm{PO}_{4}, 250 \mathrm{mM}$; and Tris- $\mathrm{HCl}, 75$ $\mathrm{mM}$ at $\mathrm{pH}$ 7.4; GTP, $100 \mu \mathrm{M}$; [2P]NAD, $5 \mu \mathrm{Ci}$; NADP, $5 \mathrm{mM}$; and $\mathrm{NAD}, 100 \mu \mathrm{M}$. The reaction was terminated by the addition of $10 \mathrm{mM}$ NAD in $50 \mathrm{mM}$ Tris- $\mathrm{HCl}$ and $4 \mathrm{mM}$ EDTA at $\mathrm{pH} 7.4$ and centrifuged at $7,000 \mathrm{~g}$ for $5 \mathrm{~min}$. The pellet was then dissolved and incubated for 5 min at $95^{\circ} \mathrm{C}$ in a $20-\mu \mathrm{l}$ solution containing Tris- $\mathrm{HCl}, 20 \mathrm{mM}$; EDTA, 1 $\mathrm{mM}$; dithiothreitol, $1 \mathrm{mM}$; and $1 \%$ cholate at $\mathrm{pH}$ 7.4. A $30-\mu \mathrm{l}$ solution containing $10 \mathrm{mM} N$-ethylmalemide was then added and the resultant mixture was maintained at room temperature for $15 \mathrm{~min}$. SDS-PAGE was carried out using the method of Laemmli (15).

Inactivation of $G_{i}$. Inactivation of $\mathrm{G}_{\mathrm{i}}$ was accomplished by ADP-ribosylation with pertussis toxin. Freshly isolated guinea pig ventricular cells were incubated with $1 \mu \mathrm{g} / \mathrm{ml}$ of pertussis toxin and minimal essential medium for $2-5 \mathrm{~h}$ at $37^{\circ} \mathrm{C}$. Before any voltage clamp experiments were performed the pertussis toxin-treated cells were superfused with external solution containing $10 \mu \mathrm{M}(-)$-propranolol for at least $10 \mathrm{~min}$.

Measurement of phosphodiesterase activity. Cyclic AMP phosphodiesterase activity was measured as previously described $(16,17)$. Single ventricular myocytes were enzymatically isolated by the method described above from eight guinea pigs. The average yield of clear rod-shaped cells was $46 \pm 14 \%$ (mean $\pm \mathrm{SD}$ ). Cells were incubated in minimal essential medium and $10 \mu \mathrm{M}(-)$-propranolol for $2 \mathrm{~h}$ at $37^{\circ} \mathrm{C}$ with (a) $100 \mu \mathrm{M}$ (-)-phenylephrine. (b) $1 \mu \mathrm{g} / \mathrm{ml}$ of pertussis toxin, and (c) $100 \mu \mathrm{M}(-)$-phenylephrine and $1 \mu \mathrm{g} / \mathrm{ml}$ of pertussis toxin before phosphodiesterase activity was determined. Each determination was performed in triplicate.

\section{Results}

ATP and cardiac calcium current. Initial experiments were directed toward evaluating the stability of the preparation in the presence and the absence of ATP since it is well known that inclusion of millimolar amounts of ATP in the suction pipette prevents $I_{\mathrm{Ca}}$ rundown during single-cell voltage-clamp experiments (18). The ability of ATP to prevent $I_{\mathrm{Ca}}$ rundown is illustrated in Fig. 1, $a$ and $b$. When $5 \mathrm{mM}$ ATP was present in the pipette, maximum $I_{\mathrm{Ca}}$ amplitude in response to a depolarizing step to $0 \mathrm{mV}$ remained stable for at least $38 \mathrm{~min}$ after rupture of the membrane patch. This figure also illustrates a more important feature for the present study, i.e., there was no increase in the magnitude of $I_{\mathrm{Ca}}$ even when exogenous ATP was readily available. This lack of effect of ATP on $I_{\mathrm{Ca}}$ is illustrated in Fig. $1 c$, which demonstrates that in the basal state the maximum $I_{\mathrm{Ca}}$ recorded in the presence and the absence of $5 \mathrm{mM}$ ATP was not significantly different. In 31 cells, the mean maximum $I_{\mathrm{Ca}}$ recorded in the absence of ATP in the patch pipette was $921 \pm 258 \mathrm{pA}$ (mean $\pm \mathrm{SD})$, whereas mean maximum $I_{\mathrm{Ca}}$ recorded from 25 cells in the presence of $5 \mathrm{mM}$ ATP in the patch pipette was $961 \pm 231 \mathrm{pA}$.

Tonic inhibition of calcium current. In cardiac myocytes direct application of cAMP stimulates $I_{\mathrm{Ca}}(19-21)$. Since adenylyl cyclase activity is under the dual control of the gua-

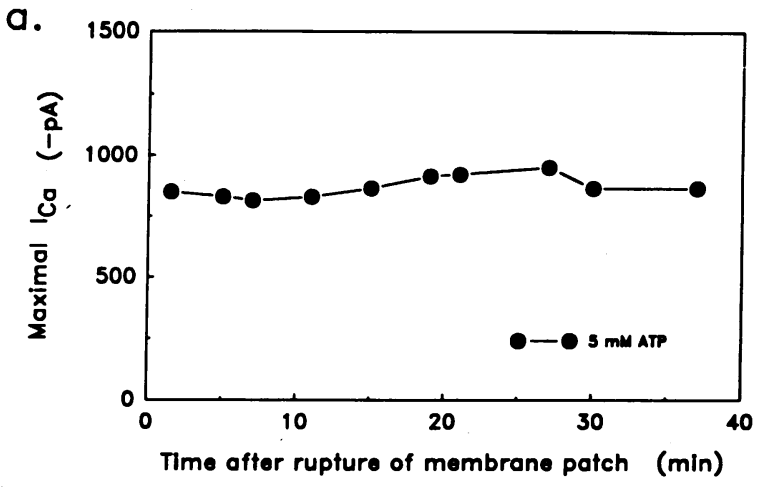

b.
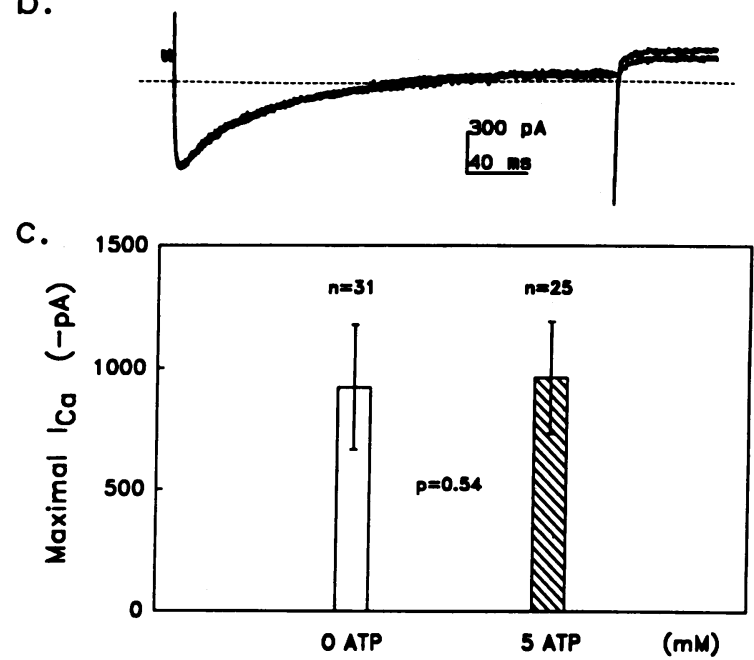

Figure 1. Effect of ATP on the cardiac calcium channel. (a) Inclusion of $5 \mathrm{mM}$ ATP in the pipette prevented calcium current rundown. The maximal peak calcium current evoked by a step depolarization from -40 to $0 \mathrm{mV}$ remained stable for at least $38 \mathrm{~min}$. Cell CTRL01. (b) Superimposed current recordings in response to a clamp step from a holding potential of $-50 \mathrm{mV}$ to a membrane voltage of $-10 \mathrm{mV}$ obtained 5 and $37 \mathrm{~min}$ after achieving the whole-cell clamp configuration. The interrupted line represents zero current level. (c) Effect of ATP on the magnitude of the cardiac calcium channel. Inclusion of $5 \mathrm{mM}$ ATP in the pipette solution did not augment the magnitude of calcium current. The basal maximal peak calcium current was similar with or without ATP in the pipette solution. Error bars represent \pm SD.

nine nucleotide stimulatory protein $\left(\mathrm{G}_{\mathrm{s}}\right)$ and one or more inhibitory $G$ proteins (termed for simplicity $G_{i}$ ), one possible explanation for the lack of effect of ATP on the $I_{\mathrm{Ca}}$ is "tonic" inhibition of adenylyl cyclase activity in the basal state by one or more forms of $G_{i}$. In the presence of such tonic inhibition, cAMP formation would not be increased despite adequate levels of ATP in the pipette, thereby preventing augmentation of $I_{\mathrm{Ca}}$. To test this hypothesis we examined the effects of pertussis toxin on $I_{\mathrm{Ca}}$. Pretreatment with pertussis toxin inhibited the subsequent ability of the toxin to ADP-ribosylate a $40-\mathrm{kD}$ band on SDS-PAGE (Fig. 2). In the presence of $5 \mathrm{mM}$ ATP in the pipette, cells pretreated with pertussis toxin demonstrated a large surge of $I_{\mathrm{Ca}}$ which reached a peak of $236 \%$ above control $\sim 5$ min after membrane patch rupture (Fig. 3, $a$ and $b$ ). The current then gradually declined over the next $35 \mathrm{~min}$. This is in sharp contrast to the control cell shown in Fig. 1, $a$ and $b$, in which ATP had no appreciable effect on the current magnitude over time. In five cells pretreated with pertussis toxin the 


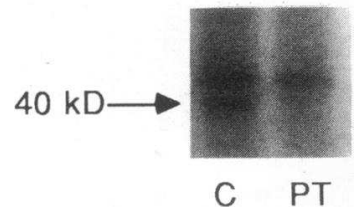

Figure 2. Autoradiogram of an SDSPAGE experiment demonstrating ADP-ribosylation of a 40-kD band (arrow) by pertussis toxin and inhibition of ADP-ribosylation by pertussis toxin pretreatment. (Left lane) A representative preparation of guinea pig single ventricular myocytes incubated for $2 \mathrm{~h}$ with pertussis toxin in the presence of [ $\left.{ }^{32} \mathrm{P}\right]$ NAD. $C$, control. (Right lane) Identical membrane preparation obtained from intact cells which had been pretreated with $1 \mu \mathrm{g} / \mathrm{ml}$ pertussis toxin $(P T)$ for $5 \mathrm{~h}$. This experiment was repeated three additional times with similar results.

mean maximum $I_{\mathrm{Ca}}$ was $1,520 \pm 906 \mathrm{pA}$ at $0.5 \pm 0.1 \mathrm{~min}$ after rupture of the membrane patch to achieve the whole-cell voltage clamp configuration (Fig. $3 c$ ). It increased to $3,028 \pm 1,829$ pA at $7 \pm 1 \mathrm{~min}$. After $23 \pm 2 \mathrm{~min}$ the current amplitude decreased to $1,644 \pm 729 \mathrm{pA}$. The augmentation of $I_{\mathrm{Ca}}$ in pertussis toxin-treated cells occurred only if exogenous ATP was available in the patch pipette. In the absence of exogenous ATP there was no enhancement or variation in $I_{\mathrm{Ca}}$ amplitude with time (Fig. $3 a$ ).

Effect of $\alpha_{1}$-agonism on the augmented calcium current. We asked whether an $\alpha_{1}$-adrenergic agonist could modulate $I_{\mathrm{Ca}}$ in our system and whether this effect depends on the presence of $\mathrm{G}_{i}$ and ATP. As shown in Fig. 4, with $5 \mathrm{mM}$ ATP in the pipette, $100 \mu \mathrm{M}(-)$-phenylephrine in the presence of $10 \mu \mathrm{M}$ $(-)$-propranolol totally inhibited the rise in $I_{\mathrm{Ca}}$ produced by pertussis toxin. This effect was completely reversed by $100 \mathrm{nM}$ terazosin, a selective $\alpha_{1}$-adrenergic antagonist (Fig. 4). To determine whether the inhibition of $I_{\mathrm{Ca}}$ was the result of $\alpha_{1^{-}}$ adrenergic augmentation of ATP hydrolysis (22), we measured cAMP-dependent phosphodiesterase activity after incubation of cardiac myocytes with $100 \mu \mathrm{M}(-)$-phenylephrine and 10 $\mu \mathrm{M}(-)$-propranolol under conditions similar to those of the whole-cell voltage clamp experiments. The cAMP-dependent phosphodiesterase activities for control, (-)-phenylephrine, pertussis toxin, and $(-)$-phenylephrine plus pertussis treatment were $24.9 \pm 6.7,25.5 \pm 7.4,32.6 \pm 10.5$, and $28.5 \pm 10.0 \mathrm{p}$ $\mathrm{mol} / \mathrm{min}$ per mg protein, respectively (mean $\pm \mathrm{SD}, n=8$ ). When compared to control, incubation with $100 \mu \mathrm{M}(-)-$ phenylephrine did not increase cAMP-dependent phosphodiesterase activity. In addition, none of the other two treatments significantly altered the enzyme activity (one-way analysis of variance with repeated measures; $F=2.41, P>0.05$, $n=8$ ).

\section{Discussion}

Occupation of $\beta$-adrenergic receptors by norepinephrine results in coupling of these receptors to $G_{s}$, leading to activation of adenylyl cyclase and subsequently of cAMP-dependent protein kinase which is involved in calcium channel phosphorylation; cholinergic agonism inhibits this response $(2,3$, 23). Calcium channel phosphorylation enhances $I_{\mathrm{Ca}}$ either by an increase in the number of functionally available channels $(2,24)$ or by an increase in the probability that an individual channel will open at any given voltage (25). A family of GTPsensitive proteins modulates the interaction between stimulatory and inhibitory cell membrane receptors and a variety of second messengers, including cAMP, inositol trisphosphate, protein kinase $C$, and diacylgylcerol $(26,27)$. The influence of $\mathrm{G}$ proteins on the calcium current is complex and depends on the cell studied (for a review, see Rosenthal et al. [27]). Direct
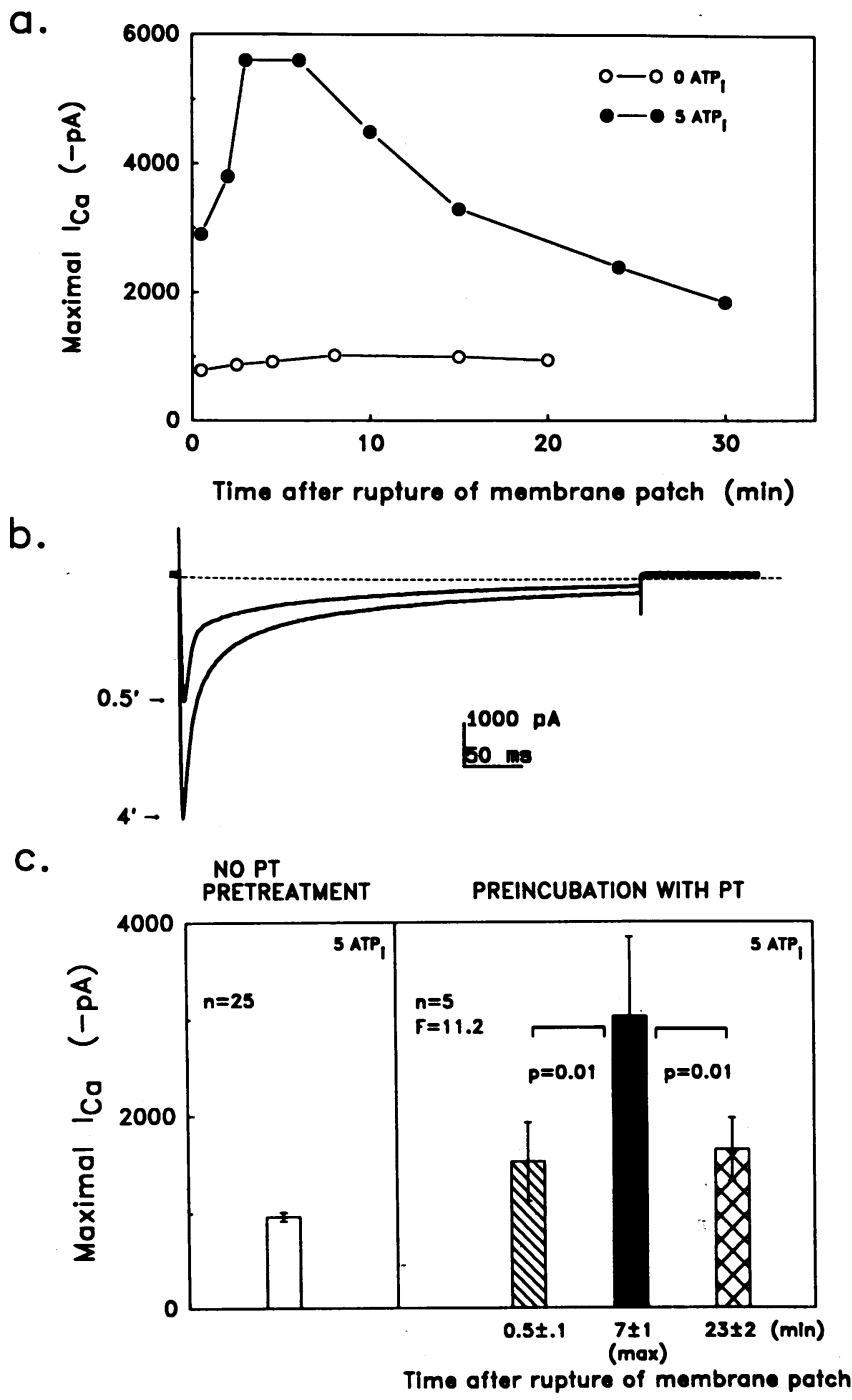

Figure 3. Effect of ATP on $I_{\mathrm{Ca}}$ in pertussis toxin-treated cells. (a) In cells preincubated with pertussis toxin, the presence of $5 \mathrm{mM}$ ATP in the pipette resulted in a large surge of $I_{\mathrm{Ca}}$ which reached a peak at about 5 min after rupture of the membrane patch to achieve the whole-cell voltage clamp configuration (O). Cell PT01. The current then gradually declined over the next $35 \mathrm{~min}$. After preincubation with pertussis toxin, without ATP in the pipette, the magnitude of the maximal peak current remained constant and unaugmented $(O)$. Cell PT02. (b) Current recordings obtained from a pertussis toxintreated cell in response to a depolarization from -40 to $0 \mathrm{mV}$ at 0.5 and $4 \mathrm{~min}$ after rupture of membrane patch. The interrupted line represents zero current level. Cell PT01. (c) The mean maximal peak $I_{\mathrm{Ca}}$ magnitude of 5 cells at 7 min was significantly larger than that 0.5 and $23 \mathrm{~min}$ after establishing the whole-cell clamp configuration. At $23 \mathrm{~min} I_{\mathrm{Ca}}$ returned to the initial level in most cells. Statistical comparisons were performed using one-way analysis of variance with repeated measures. The magnitude of the maximal peak $I_{\mathrm{Ca}}$ from 25 cells not treated with pertussis toxin recorded with $5 \mathrm{mM}$ ATP in the internal solution is included on the left for comparison. PT, pertussis toxin. Error bars represent $\pm \mathrm{SE}$

effects of $G_{s}$ on the calcium channel have also been reported (28).

Pertussis toxin has been used as a probe to irreversibly ADP-ribosylate $G_{i}$, including $G_{i}$ in cardiac tissue (3) and $G_{0}$, a 39-kD guanine nucleotide binding protein prevalent in neural tissue (29). Our data indicate that, in the presence of ATP in 


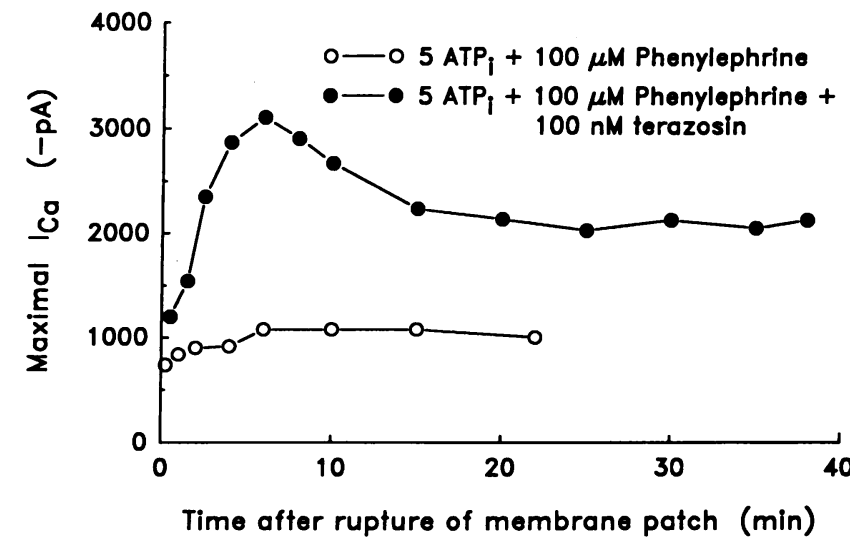

Figure 4. Effect of $\alpha_{1}$-adrenergic stimulation on $I_{\mathrm{Ca}}$ in pertussis toxin-treated cells. In the presence of $100 \mu \mathrm{M}(-)$-phenylephrine and $10 \mu \mathrm{M}(-)$-propranolol in the external solution and $5 \mathrm{mM}$ ATP in the internal solution, there was no increase in $I_{\mathrm{Ca}}(\mathrm{O})$. Cell PT05. This inhibition is an $\alpha_{1}$-adrenergic effect because it was reversed when $100 \mathrm{nM}$ terazosin, a selective $\alpha_{1}$-adrenergic antagonist, was added to the external solution together with $100 \mu \mathrm{M}(-)$-phenylephrine (๑). Cell PT10. These experiments were repeated four times with similar results. $5 \mathrm{ATP}_{\mathrm{i}}, 5 \mathrm{mM}$ ATP in the pipette solution.

the pipette, incubation with pertussis toxin results in a large surge of $I_{\mathrm{Ca}}$ after establishment of the whole-cell voltage clamp configuration, an observation which has not been previously reported. As indicated in Fig. $3 a$, the increase in $I_{\mathrm{Ca}}$ did not occur in the absence of exogenous ATP in the pipette. These data are in sharp contrast to the control cells (Fig. 1, $a$ and $c$ ) in which ATP had no appreciable effect on the magnitude of $I_{\mathrm{Ca}}$ Although Hescheler et al. (3) noted a modest $60 \%$ increase in $I_{\mathrm{Ca}}$ after pertussis toxin treatment, these investigators did not report a large surge in $I_{\mathrm{Ca}}$ with time nor did they test the effects of ATP. Our observations are consistent with the possibility that tonic inhibition of adenylyl cyclase activity by $G_{i}$ or by a similar protein that is ADP-ribosylated by pertussis toxin prevents excessive calcium channel opening in the basal state and thereby acts as a homeostatic mechanism. These data do not exclude the possibility that $G_{i}$ or another protein acting as a pertussis toxin substrate bypasses the adenylyl cyclase-cAMP cascade and interacts directly with the calcium channel.

Fig. 3 illustrates another significant finding. Despite a continuous supply of exogenous ATP via the pipette, the peak $I_{\mathrm{Ca}}$ declined rapidly after an initial surge. At the end of $23 \mathrm{~min}$, it reached the same level as at $0.5 \mathrm{~min}$. Bean et al. (24) observed a similar decline in $I_{\mathrm{Ca}}$ despite continuous $\beta$-adrenergic stimulation with isoproterenol in frog ventricular heart cells. One possible explanation for this decline is that the increase in cAMP resulting from incubation with a $\beta$-adrenergic agonist activates intracellular phosphodiesterase, thereby accelerating the breakdown of cAMP in an autoregulatory manner (30).

In contrast to the preliminary report of Yatani et al. (31), in which a direct effect of $\mathrm{G}_{\mathrm{s}}$ on $I_{\mathrm{Ca}}$ in guinea pig atrial myocytes was noted, our observations indicate that an adequate level of ATP is a necessary prerequisite for pertussis toxin to act in an intact cell system. Our data suggest that this effect is mediated by a mechanism requiring channel phosphorylation. Our results also are in agreement with those of Armstrong and Eckert (32), who demonstrated that the dihydropyridine sensitive class of voltage-activated calcium channels must be phosphor- ylated for the channels to open when the membrane is depolarized.

In many systems, inhibition of adenylyl cyclase activity is mediated by an $\alpha$-adrenergic receptor, particularly the $\alpha_{2}$ adrenergic receptor (33). The guinea pig heart is richly endowed with $\alpha_{1}$-adrenergic receptors (34), and we have recently reported in neonatal rat ventricular myocytes that agonist occupation of the $\alpha_{1}$-adrenergic receptor inhibits cAMP formation through $G_{i}$, an effect which is prevented by pertussis toxin pretreatment (11). We wondered whether a similar effect could be demonstrated on $I_{\mathrm{Ca}}$. Our data indicate that $I_{\mathrm{Ca}}$ is under the control of the $\alpha_{1}$-adrenergic receptor in cardiac cells and that this inhibitory effect does not involve a pertussis toxin-sensitive substrate. These observations are in marked contrast to those of other investigators who were unable to demonstrate an effect of $\alpha_{1}$-adrenergic agonists on the slow inward calcium current in ventricular preparations from adult guinea pig (8), cat (9), or rat tissue (10). However, our data are consistent with those of Iwakura et al. (35), who in a preliminary report noted that calcium transients as measured by the indicator fura- 2 was diminished by treatment with norepinephrine in the presence of propranolol after $\mathrm{KCl}$ depolarization.

In most systems in which the calcium channel has been studied, hormone modulation via $\mathrm{G}_{\mathrm{i}}$ or $\mathrm{G}_{0}$ appears to be inhibitory $(3,20)$. The mechanism of $\alpha_{1}$-adrenergic receptor inhibition of $I_{\mathrm{Ca}}$ that we observed at present is unclear. We considered the possibility that (-)-phenylephrine activated phosphodiesterase (22) leading to a decrease in cAMP and hence in calcium channel phosphorylation. However, we were unable to demonstrate such a (-)-phenylephrine-induced alteration of phosphodiesterase activity in our myocyte preparation. An additional possibility that requires further investigation is activation by $\alpha_{1}$-adrenergic agonism of a hitherto unidentified $G$ protein which either inhibits adenylyl cyclase activity or directly affects the calcium channel. It also is known that $\alpha_{1-}$ adrenergic occupation stimulates the production of diacylgylcerol which in turn activates protein kinase $C$, which can either augment $(36)$ or inhibit $(6,37) I_{\mathrm{Ca}}$ in a variety of neuronal tissues. On the other hand, in feline ventricular cells, phorbol 12-myristate 13-acetate, a putative protein kinase $\mathrm{C}$ activator, had no effect on $I_{\mathrm{Ca}}(9)$.

Although the mechanism of action of $\alpha_{1}$-adrenergic agonism remains to be resolved, our findings clearly indicate that in cardiac cells the processes controlling calcium homeostasis require an adequate cellular supply of ATP, are likely under the "tonic" influence of a pertussis toxin sensitive substrate, and are subject to control by the $\alpha_{1}$-adrenergic receptor via a signal transduction mechanism not coupled to a pertussis toxin-sensitive substrate. These observations have implications for understanding abnormalities that may occur under pathophysiological conditions, such as myocardial ischemia and congestive heart failure, where alterations in $\alpha_{1}$-adrenergic receptors, ATP levels, and $G$ protein function are known to occur (38-40).

\section{Acknowledgment}

We thank Mr. Robert Berg and Mr. Norm Honbo for technical assistance.

This work was supported by the Department of Veterans Affairs, Research Service, Washington, DC, and by Program Project Grant HL-25847 from the National Heart, Lung and Blood Institute, Bethesda, Maryland. 


\section{References}

1. Tsien, R. W. 1983. Calcium channels in excitable cell membranes. Annu. Rev. Physiol. 45:341-358.

2. Reuter, H. 1983. Calcium channel modulation by neurotransmitters, enzymes and drugs. Nature (Lond.) 301:569-574.

3. Hescheler, J., M. Kameyama, and W. Trautwein. 1986. On the mechanism of muscarinic inhibition of the cardiac Ca current. Pflügers Arch. Eur. J. Physiol. 407:182-189.

4. Forscher, P., and G. S. Oxford. 1985. Modulation of calcium channels by norepinephrine in internally dialyzed avian sensory neurons. J. Gen. Physiol. 85:743-763.

5. Holz, G. G., S. G. Rane, and K. Dunlap. 1986. GTP-binding proteins mediate transmitter inhibition of voltage-dependent calcium channels. Nature (Lond.). 319:670-672.

6. Rane, S. G., and K. Dunlap. 1986. Kinase C activator 1,2oleoylacetylglyerol attenuates voltage-dependent calcium current in sensory neurons. Proc. Natl. Acad. Ści. USA. 83:184-188.

7. Brückner, R., and H. Scholz. 1984. Effects of $\alpha$-adrenoceptor stimulation with phenylephrine in the presence of propranolol on force of contraction, slow inward current and cyclic AMP content in bovine heart. Br. J. Pharmacol. 82:223-232.

8. Hescheler, J., H. Nawrath, M. Tang, and W. Trautwein. 1988. Adrenoceptor-mediated changes of excitation and contraction in ventricular heart muscle from guinea-pigs and rabbits. J. Physiol. (Lond.). 397:657-670.

9. Hartmann, H. A., N. J. Mazzocca, R. B. Kleinman, and S. R. Houser. 1988. Effects of phenylephrine on calcium current and contractility of feline ventricular myocytes. Am. J. Physiol. 255:H1173H1180.

10. Apkon, M., and J. M. Nerbonne. 1988. $\alpha_{1}$-Adrenergic agonists selectively suppress voltage-dependent $\mathrm{K}^{+}$currents in rat ventricular myocytes. Proc. Natl. Acad. Sci. USA. 85:8756-8760.

11. Barrett, S., N. Honbo, and J. S. Karliner. 1987. An alpha ${ }_{1}$-receptor acting through a guanine nucleotide regulatory protein modulates cAMP release in myocardial cells. Circulation. 76:IV-62. (Abstr.)

12. Silver, L. H., E. L. Hemwell, T. A. Marino, and S. R. Houser. 1983. Isolation and morphology of calcium tolerant feline ventricular myocytes. Am. J. Physiol. 245:H891-H896.

13. Hamill, O., A. Marty, E. Neher, B. Sakmann, and E. J. Sigworth. 1981. Improved patch-clamp techniques for high-resolution current recording from cells and cell-free membrane patches. Pflügers Arch. Eur. J. Physiol. 391:85-100.

14. Morris, S. A., and J. P. Bilezikian. 1986. Modification of the adenylate cyclase complex during differentiation of cultured myoblasts. J. Cell. Physiol. 127:28-38.

15. Laemmli, U. K. 1970. Cleavage of structural proteins during the assembly of the head of bacteriophage $\mathrm{T}_{4}$. Nature (Lond.). 227:680-685.

16. Filburn, C. R., and J. Karn. 1973. An isotopic assay of cyclic 3',5'-nucleotide phosphodiesterase with aluminum oxide columns. Anal. Biochem. 52:505-516.

17. Alvarez, R., A. Taylor, J. J. Fazzari, and J. R. Jacobs. 1981. Regulation of cylic AMP metabolism in human platelets: sequential activation of adenylate cyclase and cylic AMP phosphodiesterase by prostaglandins. Mol. Pharmacol. 20:302-309.

18. Belles, B., C. O. Malecot, J. Hescheler, and W. Trautwein 1988. "Run-down" of the Ca current during long whole-cell recordings in guinea pig heart cells: role of phosphorylation and intracellular calcium. Pflügers Arch. Eur. J. Physiol. 411:353-360.

19. Tsien, R. W. 1973. Adrenaline-like effects of intracellular iontophoresis of cyclic AMP in cardiac Purkinje fibers. Nature (Lond.) 245:120-122.

20. Trautwein, W., J. Taniguchi, and A. Noma. 1982. The effect of intracellular nucleotides and calcium on the action potential and acetylcholine response of isolated cardiac cells. Pflügers Arch. Eur. J. Physiol. 392:307-314.
21. Nargeot, J., J. M. Nerbonne, J. Engels, and H. Lester. 1983. Time course of the increase in the myocardial slow inward current after a photochemically generated concentration jump of intracellular cAMP. Proc. Natl. Acad. Sci. USA. 80:2395-2399.

22. Buxton, I. L., and L. L. Brunton. 1985. Action of the cardiac $\alpha_{1}$-adrenergic receptor: activation of cyclic AMP degradation. J. Biol. Chem. 26:6733-6737.

23. Kameyama, M., F. Hofmann, and W. Trautwein. 1985. On the mechanism of beta-adrenergic regulation of the $\mathrm{Ca}$ channel in the guinea-pig heart. Pflügers Arch. Eur. J. Physiol. 405:285-293.

24. Bean, B. P., M. C. Nowycky, and R. W. Tsien. 1984. $\beta$-Adrenergic modulation of calcium channels in frog ventricular heart cells. Nature (Lond.). 307:371-375.

25. Brum, G., W. Osterrieder, and W. Trautwein. 1984. $\beta$-Adrenergic increase in the calcium conductance of cardiac myocytes studied with the patch clamp. Pflügers Arch. Eur. J. Physiol. 401:111-118.

26. Berridge, M. J. and R. F. Irvine. 1984. Inositol trisphosphate, a novel second messenger in cellular signal transduction. Nature (Lond.). 312:315-321.

27. Rosenthal, W., J. Hescheler, W. Trautwein, and G. Schultz. 1988. Control of voltage-dependent $\mathrm{Ca}^{2+}$ channels by $\mathrm{G}$ protein-coupled receptors. FASEB. (Fed. Am. Soc. Exp. Biol.) J. 2:2784-2790.

28. Imoto, Y., A. Yatani, J. P. Reeves, J. Codina, L. Birnbaumer, and A. M. Brown. 1988. $\alpha$-Subunit of $\mathrm{G}_{\mathrm{s}}$ directly activates cardiac calcium channels in lipid bilayers. Am. J. Physiol. 255:H722-H728.

29. Hescheler, J., W. Rosenthal, W. Trautwein, and G. Schultz. 1987. The GTP-binding protein, $G_{0}$, regulates neuronal calcium channels. Nature (Lond.). 325:445-447.

30. Gettys, T. W., A. J. Vine, M. F. Simonds, and J. D. Corbin. 1987. Activation of the particulate low $K_{\mathrm{m}}$ phosphodiesterase of adipocytes by addition of cAMP-dependent protein kinase. J. Biol. Chem. 263:10359-10363.

31. Yatani, A., K. Okabe, and A. M. Brown. 1989. Time course of cardiac $\mathrm{Ca}^{2+}$ current after a concentration jump of isoproterenol. Biophys. J. 55:36a. (Abstr.)

32. Armstrong, D., and R. Eckert. 1987. Voltage-activated calcium channels that must be phosphorylated to respond to membrane depolarization. Proc. Natl. Acad. Sci. USA. 84:2518-2522.

33. Exton, J. H. 1985. Mechanisms involved in $\alpha$-adrenergic phenomena. Am. J. Physiol. 248:E633-E647.

34. Karliner, J. S., P. Barnes, C. A. Hamilton, and C. T. Dollery. 1979. Alpha-adrenergic receptors in guinea pig myocardium: identifcation by binding of a new radioligand $\left({ }^{3} \mathrm{H}\right)$-prazosin. Biochem. Biophys. Res. Commun., 90:142-149.

35. Iwakura, K., Y. Watanabe, M. Hori, and H. Kusuoka. 1988. Increased $\alpha_{1}$-adrenergic receptors coupled with phosphatidylinosito response augment $\mathrm{Ca}^{2+}$ overload in cardiomyopathic hamster. Circulation. 78:II-334. (Abstr.)

36. Kaczmarek, L. K. 1986. Phorbol ester, protein phosphorylation and the regulation of neuronal ion channels. J. Exp. Biol. 124:375392.

37. Marchetti, C., and A. M. Brown. 1988. Protein kinase activator 1-oleoyl-2-acetyl-sn-glycerol inhibits two types of calcium currents in $\mathrm{GH}_{3}$ cells. Am. J. Physiol. 254:C206-C210.

38. Culling, W., M. J. Penny, G. Cunliffe, N. A. Flores, and D. J. Sheridan. 1987. Arrhythmogenic and electrophysiological effects of alpha adrenoceptor stimulation during myocardial ischemia and reperfusion. J. Mol. Cell. Cardiol. 19:251-258.

39. Horn, E. M., S. J. Corwin, S. F. Steinberg, Y. K. Chow, G. W. Neuberg, P. J. Cannon, E. R. Powers, and J. P. Bilezikian. 1988. Reduced lymphocyte stimulatory guanine nucleotide regulatory protein and $\beta$-adrenergic receptors in congestive heart failure and reversal with angiotensin converting enzyme inhibitor therapy. Circulation. 78:1373-1379.

40. Karliner, J. S., M. B. Stevens, N. Honbo, and J. I. E. Hoffman. 1989. Effects of acute ischemia in the dog on myocardial blood flow, beta receptors, and adenylate cyclase activity with and without chronic beta blockade. J. Clin. Invest. 83:474-481. 